\title{
Imprints of the 1755 tsunami in the Tróia Peninsula shoreline, Portugal
}

\author{
Luís Rebêlo $\dagger$, Susana Costas $\dagger$, Pedro Brito $\dagger$, Marco Ferraz $\dagger$, M. Isabel Prudêncioł and Christopher \\ Burbidge:
}

†Laboratório Nacional de Energia e Geologia, Estrada da Portela, Zambujal, s/n 2610-999 Amadora, Portugal

luis.rebelo@lneg.pt

susana.costas@lneg.pt

pedro.brito@lneg.pt

marco.ferraz@lneg.pt

\author{
I IST/ITN \\ Instituto Superior Técnico, Universidade \\ Técnica de Lisboa \\ Estrada Nacional 10, 2686-953 \\ Sacavém, Portugal \\ christoph@itn.pt \\ iprudenc@itn.pt
}

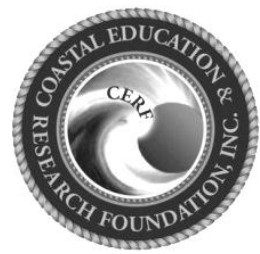

www.cerf-jcr.org

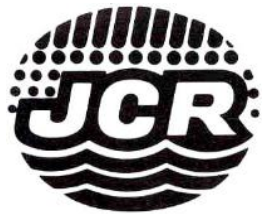

www.JCRonline.org

\section{ABSTRACT}

Rebêlo, L., Costas, S., Brito, P., Ferraz, M., Prudêncio, M. I. and Burbidge, C., 2013. Imprints of the 1755 tsunami in the Tróia Peninsula shoreline, Portugal In: Conley, D.C., Masselink, G., Russell, P.E. and O’Hare, T.J. (eds.), Proceedings $12^{\text {th }}$ International Coastal Symposium (Plymouth, England), Journal of Coastal Research, Special Issue No. 65, pp. 814-819, ISSN 0749-0208.

\begin{abstract}
A large earthquake shook the offshore region of Portugal in November $1^{\text {st }} 1755$ with an estimated magnitude of $8.5 \pm 0.3$ in the Richter scale. It lead to the massive destruction of the city of Lisbon, which was followed by intense fires. Although most of the detailed consequences of the earthquake and tsunami focused in Lisbon, the effect of tsunami destruction was also reported in other locations along the Peninsula coasts and Morocco. At Setúbal, located $30 \mathrm{~km}$ to the south of Lisbon in the Sado estuary, evidences of inundation were also documented, reporting wave heights that reached a first floor height. Despite the magnitude of the inundation in the interior of the estuary, there has not been reported any evidence of the impact of this event on the estuarine shorelines. In order to understand the consequences of such a wave on the sandy shores of the region, we explore the inlet shoreline and seaward exposed region of the estuary, the Tróia peninsula. To do so, we integrate multiple types of data and information: dune ridge position were extracted from aerial photographs, shorelines from the historical maps, shoreline progradation rates, Ground Penetrating Radar profiles and optically stimulated dating of barrier sediments. This information allows us to reconstruct the shoreline following the tsunami, documenting a greater impact towards the inlet where the water flow concentrate as it entered the estuary. The impact of the tsunami in Tróia peninsula translates on the erosion of about 1000 years of barrier deposits within the spit end.
\end{abstract}

\section{ADDITIONAL INDEX WORDS: Tsunami erosion, coastal evolution, dune dating.}

\section{INTRODUCTION}

In 1755 , the south and west coast of Portugal was hit by a tsunami as a consequence of the well-known 1755 Lisbon earthquake. This earthquake, that reached an estimated magnitude of $8.5 \pm 0.3$ (Solares and Arroyo, 2004), was followed by a large tsunami which lead to an intense destruction and flooding on coastal populations and lowlands (Baptista and Miranda, 2009).

The effects of the tsunami on these populations are well documented due to the large number of deaths and material losses generated by the earthquake and the tsunami. The devastating effects of the tsunami in Lisbon and along the Algarve region, southern Portugal, are particularly well documented. In addition, to the historical references, research on coastal deposits has reported the occurrence of tsunami generated deposits in several estuaries in southern Portugal (Costa et al., 2012; Font et al., 2010). At Setúbal, located $30 \mathrm{~km}$ to the south of Lisbon in the

DOI: $10.2112 /$ SI65-138.1 received 07 December 2012; accepted 06

March 2013

(C) Coastal Education \& Research Foundation 2013
Sado estuary, evidences of tsunami destruction were also documented, reporting wave heights that reached the first floor.

The Sado estuary is separated from the Atlantic Ocean by a long $(25 \mathrm{~km})$ and thin (between 0.4 and $1.5 \mathrm{~km}$ width) sand barrier, the Tróia peninsula (figure 1). The complex growth of the spit end partially isolated a water body leading to the formation of the Caldeira lagoon. At present, Caldeira is connected to the estuary.

The estuary mouth consists of a $2 \mathrm{~km}$ wide inlet confined to the north by the Arrábida chain, a W-E rocky promontory, and to the south by the spit end of the sandy Tróia peninsula.

A tsunami wave approaching from SW or WSW, as modeled by the different hypothesized epicenters, would suffer a funnel effect in the estuary mouth due to the configuration of the present shoreline. Considering that Tróia peninsula is mainly built by marine, estuarine and aeolian sandy deposits, large-scale erosion due to the impact of the large tsunami may have occur in the peninsula. Here, we explore the sandy barrier in order to test this hypothesis and to shed light on the adaptation of sandy shorelines to destructive events such as tsunamis. 


\section{METHODS}

In an attempt to identify the imprints left by the tsunami two assumptions have been made: (1) Foredunes are good indicators of shoreline position (Psuty, 1992) since they are formed in the upper part of the beach. In prograding coasts, foredunes may be "trapped" inland, resulting in the formation of foredune successions. Consequently, these inactive dunes can be used as proxies for paleoshorelines. (2) Tsunamis are typically destructive events.

Therefore, the method used to find the tsunami imprints consisted of systematically mapping dune ridges to find the limit between pre and post-tsunami formations. To do so, three different approaches were used for the identification of the paleoshorelines: (1) shorelines position from old maps; (2) foredune crestline sequence analysis from aerial photography, and (3) Ground Penetrating Radar (GPR) profiles perpendicular to the present shoreline.

In addition to the ages obtained from the analysis of the foredune from maps and aerial photographs, and to extend the temporal record back in time, sediment samples from the coastal barrier were dated by Optically Stimulated Luminescence (OSL) (table 1).

A GIS was employed to perform rectification of aerial photos and maps, build a digital terrain model from altimetry data, create the topography profiles, and estimate shoreline displacement rates. The digital terrain model was developed using one meter spaced altimetry contour lines from a detailed survey made by IMOAREIA in 1995. Ground truth was made to confirm the position of the interpreted crestlines with the real morphology.

\section{Historical maps}

The peninsula coastline and dune/beach limit in historical maps is usually not geographically precise. The same happens with dune morphology. This problem seems to be enhanced as older the map is. With some of these maps, it is not possible to quantify the costal changes. However, the shape and relative position of the different sectors of the coast gives important indications about the trend of the evolution from the past. This is especially relevant if we are able to link those shapes and locations with old foredunes seen in more recent datasets. Moreover, the position of those limits gives an important contribution to date foredunes ridges that are visible in recent aerial photos. Since dune morphology is not

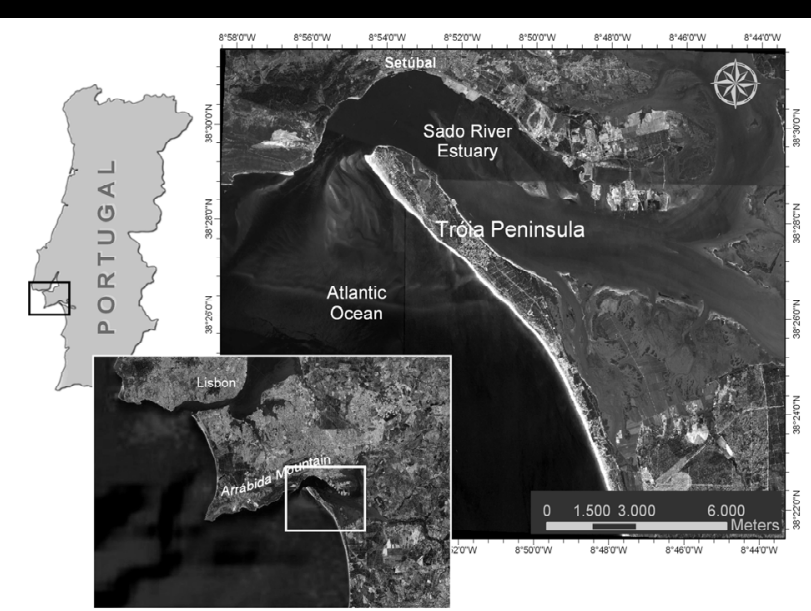

Figure 1. Tróia Peninsula location. Background image adapted from Google ${ }^{\mathrm{TM}}$ and georeferenced according to Datum "Lisboa" (adapted from Rebêlo et al, 2009).

well represented in old maps, the separation between the beach and dune environments was used as the coastline indicator.

The four historical maps used to analyze coastal evolution are dated from 1760 (Inselin), 1802 (Folque), 1852 (Vincedon) (figure 2) and 1928 (Instituto Hidrográfico). The three more recent maps were subjected to geo-referencing process. Due to the lack of control points in the Peninsula, detailed geo-referencing was impossible. Image adjustments were made using the coastline sectors that are believed to have suffered smaller changes: the lagoon shape contour, the bay side coastline and the northern and western margins of the estuary.

\section{Aerial photography and orthophotomaps}

Several datasets were used to analyze subtract the sequence of foredune crestlines. From Rebêlo et al., 2009, dunefield interpretation was used in order to evaluate the past evolution. Recent evolution was based on the interpretation of Ferraz, 2007. This author used aerial photos of five flights (1947, 1958, 1967, 1976 and 1986) and two orthophotomaps (2000 and 2005) for recent coastline interpretation and dune evolution.
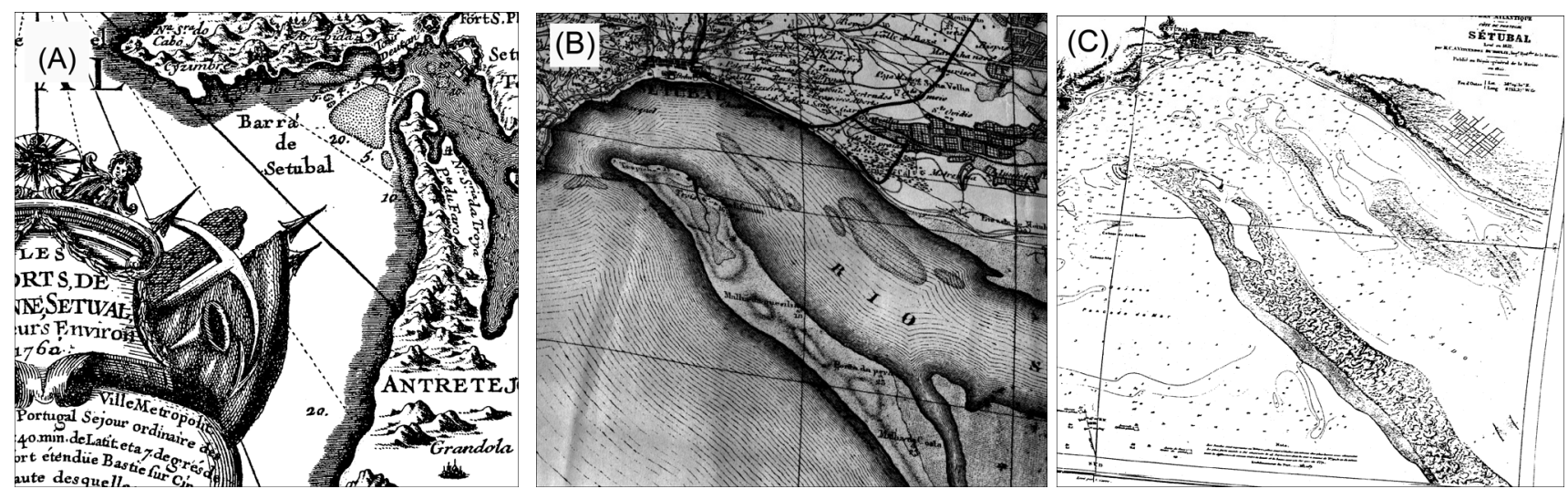

Figure 2. Three historical maps of the northern part of Tróia Peninsula. (A) 1760, (B) 1802; and (C) 1852. 


\section{Georadar Profiles}

GPR profiles were collected across the coastal barrier to visualize the internal architecture of the barrier and investigate the occurrence of particular imprints of the tsunami-generated erosion on the barrier. For that, we have collected around $4 \mathrm{~km}$ of GPR lines across the barrier using a Ramac GPR system (made by MALA Geoscience of Sweden) with a $250 \mathrm{MHz}$ antenna (figure 3 ). During data acquisition, trace spacing was $5 \mathrm{~cm}$, time-window range was selected to 300 ns. Following data acquisition, GPR data were processed in sequential steps using REFLEXW software including correction for zero time, background removal, frequency bandpass filtering, gain, migration (where appropriate) and correction for topography. Topographic corrections to GPR images have been applied assuming radar velocities of $12 \mathrm{~cm} / \mathrm{ns}$ within the section above the water table, and $0.06 \mathrm{~cm} / \mathrm{ns}$ for the radargram section below the water table. These values correspond to the typical values calculated for dry and saturated sands respectively (Sensors and Software 1993). Maximum depths of penetration around $9 \mathrm{~m}$ were achieved under favorable conditions; without the influence of marine water edge. Topographic surveys were measured in simultaneous by using a GPS-RTK/GPR integrated and synchronized system.

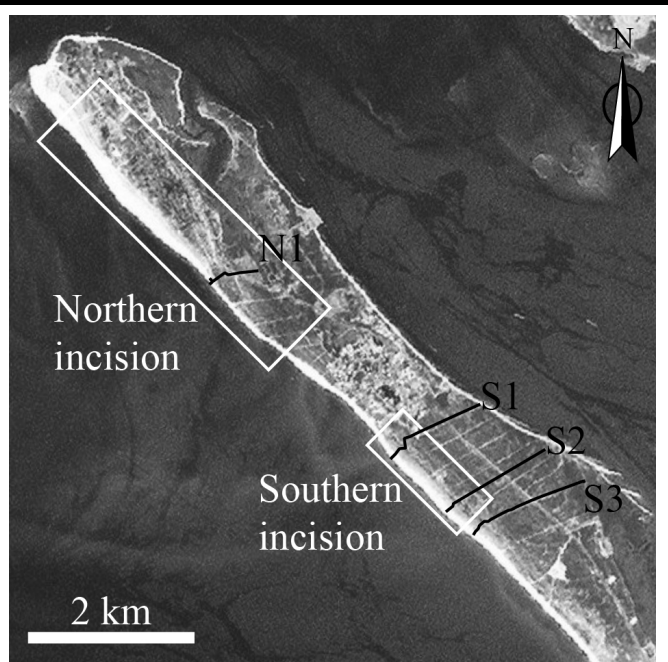

Figure 3. Location of GPR lines across the two areas of interest.

\section{Dune Dating}

Dune dating was achieved by (1) indirect methods, assuming the position of the active foredune in a particular dataset (aerial photography, ortophotomap or map) or (2) by dating the age when the sand was buried, using optically stimulated luminescence (OSL).

Sample locations were previously identified in the GPR profiles and by dune morphology analysis. Location of active foredunes was extracted from rectified maps and aerial photos in order to study the recent and historical evolution of the peninsula. 1928 foredune position was obtained from a map; 1947, 1958, 1967, 1976, 1986 from aerial photos; and 2000 and 2005 from orthophotomaps. OSL dating was used to extend the time range of the analysis, using SAR absorbed dose evaluations on ca. $200 \mu \mathrm{m}$ quartz grains isolated from samples collected ca. $1 \mathrm{~m}$ below the present surface, from cleaned sections on the upwind side of dune crests to avoid sampling reworked sand. Environmental dose rates $(\alpha, \beta, \gamma$, cosmic) were calculated based on $\mathrm{K}$, Th, and $\mathrm{U}$ concentrations evaluated by Instrumental Neutron Activation Analysis and field $\mathrm{NaI}$ gamma spectrometry, as-sampled and drained water content measurements, sample and measurement geometries, locations and burial depths (for more detailed description of the methods see Burbidge et al., Submitted, and Gouveia et al., 1994)

\section{RESULTS AND INTERPRETATION}

\section{The historical record (maps)}

Coastline configuration drawn in historical maps (figure 2) is significantly different from present (figure 4). Historical maps from 1760, 1802 and 1852 (figure 2) show two indentations: an indentation in the northern end, near the estuary entrance, and a second indentation a few kilometers to the south. This configuration contrasts with the configuration of the present coastline, which shows a more linear shape (figure 4) and suggests that this shape could be the result of the catastrophic event. Indeed, the narrower shape of the northern end of the peninsula may be interpreted as a sign of sediment removal due to the tsunami, while the undulated coastline may reflect the concentration of the erosion by the wave in particular sectors of the coast. Moreover, if these morphologic aspects are related to a disturbance episode, they must be followed by a recovery trend to its equilibrium shape in relation to local wave and tidal regimes as it is suggested by the shoreline reconstruction from aerial photographs.

Other morphological elements within the barrier point to significant changes driven by the tsunami. The communication between the Caldeira lagoon and the estuary points was markedly narrower before the tsunami increasing its width following this event. The 1760 map (figure 2, A) shows two features that could be indicative of the tsunami effects; a sand bank was identified in the estuary inlet and was interpreted as the result of the wave inflow and the subsequent deposition of the sediment eroded from the adjacent inlet shoreline; and the curved spit towards the estuary, as a result of the inflow due to the wave.

Table 1. Optically Stimulated Luminescence ages for dune sediments

\begin{tabular}{ccc}
\hline Sample reference & Age (years, A.D. $)$ & Error $( \pm$ years $)$ \\
\hline Troia-04 & 700 & 70 \\
Troia-08 & -900 & 150 \\
Troia-09 & -90 & 170 \\
Troia-10 & 530 & 70 \\
Troia-11 & 1800 & 30 \\
Troia-12 & 1840 & 20 \\
Troia-13 & 1910 & 20 \\
Troia-15 & 310 & 80 \\
Troia-16 & 1370 & 40 \\
Troia-17 & 1600 & 30 \\
Troia-18 & 1780 & 20 \\
Troia-20 & 1740 & 20 \\
Troia-21 & 1790 & 20 \\
Troia-22 & 190 & 100 \\
Troia-24 & 230 & 90 \\
Troia-25 & 110 & 70 \\
TR_210_14 & 1200 & 60 \\
TR_210_16 & 1360 & 30 \\
TR_210_20 & 390 & 60 \\
TR_210_21 & 1630 & 30 \\
TR_210_22 & 880 & 70 \\
TR_210_24 & 950 & 40 \\
\hline
\end{tabular}



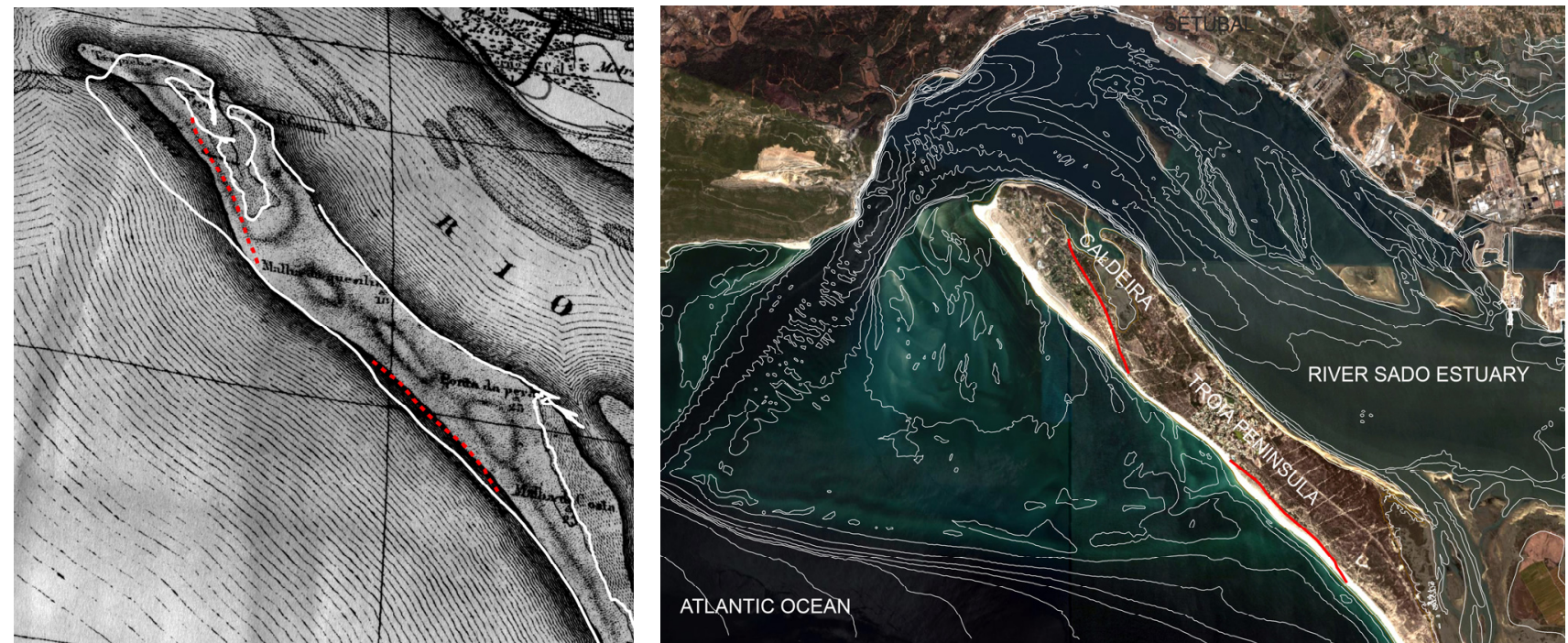

Figure 4. Geographic comparison between recent and post-tsunami coastlines. Left: 2005 coastline superimposed to the 1802 map (47 years after the event); Dashed line, obtained from dune interpretation on aerial photos, marking the tsunami erosion limit. Right: Underwater morphology, enhancing the Sado delta accumulation, and the tsunami erosion limit, on top of a $2005 \mathrm{Google}^{\mathrm{TM}}$ image.

The next available map, 1802 map (figure 2, B), is slightly more detailed than the map of 1760. It shows that the erosion associated to the tsunami remained preserved 47 years after the tsunami.

The 1852 map (figure 2, C) shows a significant progradation of the coast, mainly in the southern indentation, probably as a result of a fast beach recovery. However, the contrasted contact between the recent and more active beach/dune environments with the older dunes continues to show the indentation that is located approximately in the same position than the 1802 coastline. Dune crest analysis, performed in more recent aerial photos, also corroborates this ancient coastline position. Following the foredune succession, from the coast to the interior, a welldeveloped and almost continuous dune ridge is perceptible, indicating that the coastline, somewhere in the past, had the same curvilinear shape and occupied the position shown in the maps (figure 5). Another evidence of a sudden change is vegetation cover. Aerial photo analysis at the southern indentation coastal sector, shows a clear change in vegetation along a curvilinear line, which is approximately in the same position as the paelocoastline mentioned above. Inland of that line, the vegetation is denser, while to the ocean side, the vegetation is more sparse and the dune seems to be younger (figure 6).

\section{The sedimentary record (OSL and GPR)}

Once the historical maps were interpreted, we attempted to corroborate the initial hypothesis derived from the analysis of the map, namely "the tsunami provoked discontinuous erosion along the coastal barrier with two major indentations", with morphological evidence and the sedimentary record.

At the surface, the southern indentation is evidenced by changes in the vegetation cover and an erosional scarp that are coincident with changes in the growth rate of the peninsula. The scarp coincides with the position of the shoreline subtracted from old maps drawn after the tsunami. Dune morphology landward of the erosional scarp was partially destroyed with the formation of abundant and large blowout cutting through the foredune ridge. Internally, GPR images indicate that the erosional scarp corresponds to an erosive bounding surface showing high amplitudes and continuity. The shape of this surface suggest the erosion of the beach and the formation of an inundation surface

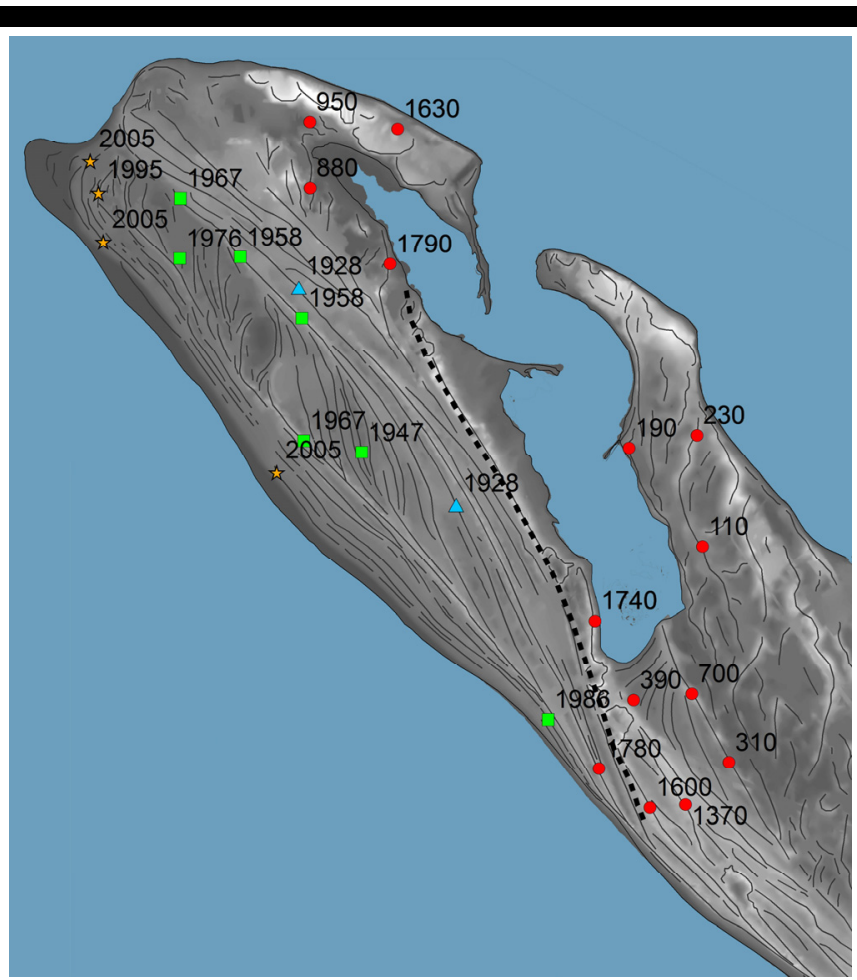

Figure 5. Digital terrain model of the north part of Tróia Peninsula. Dune crests in solid lines. Dune dates in years A.D. obtained from: stars - aerophotomaps; squares - aerophotos; triangle - historical map; circle - OSL dating. Dunes to the east of the dashed line (the erosion front caused by the tsunami) are older than the event. 


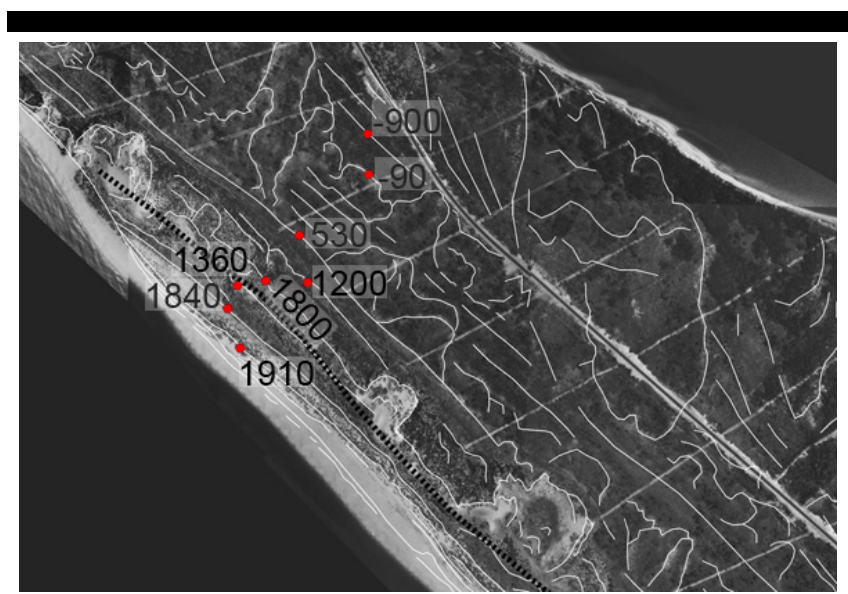

Figure 6. Southern indentation detail. Black dashed line representing the position for the erosion limit; White lines representing dune crest interpretation; Red circles representing OSL sand samples location. Values are calendar dates, AD, except where indicated.

reaching the toe of an inland dune that would be later feed by reworked aeolian sands to increase its elevation (figure 7). This surface is markedly different from the typical erosive scarps shaping the foreshore, which are shorter and steeper (figure 7).

OSL dating performed on sands from seven ancient foredune crests and one beach confirm the occurrence of significant erosion along the peninsula. The progradation rate landward of the erosional scarp is around $0.25 \mathrm{my}^{-1}$ while the rate of barrier progradation seaward of the scarp increased to approximately $1 \mathrm{my}^{-1}$ (Figure 6). The dune located inland of the erosional scarp was dated at $1800 \pm 30$ (A.D.) (figure 6), while beach sediments just seaward of the dune scarp, and beneath the bounding surface identified in the GPR were dated at $1360 \pm 30$ (A.D.). This means that the surficial sediments of the dune result from the sedimentation of sand reworked by the tsunami or after the tsunami. Inland of the erosional scarp, another limit or erosional front can be traced (figure 6). In this case, the event responsible

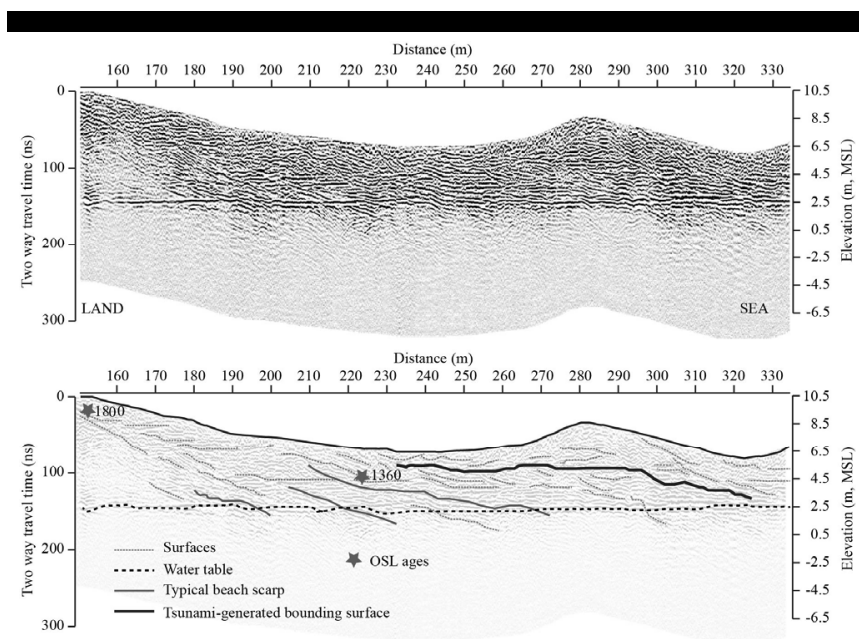

Figure 7. Georadar profile ( $\mathrm{S} 1$ in figure 3 ) and interpretation. Erosional surface suggesting the erosion of the beach and the formation of an inundation surface.

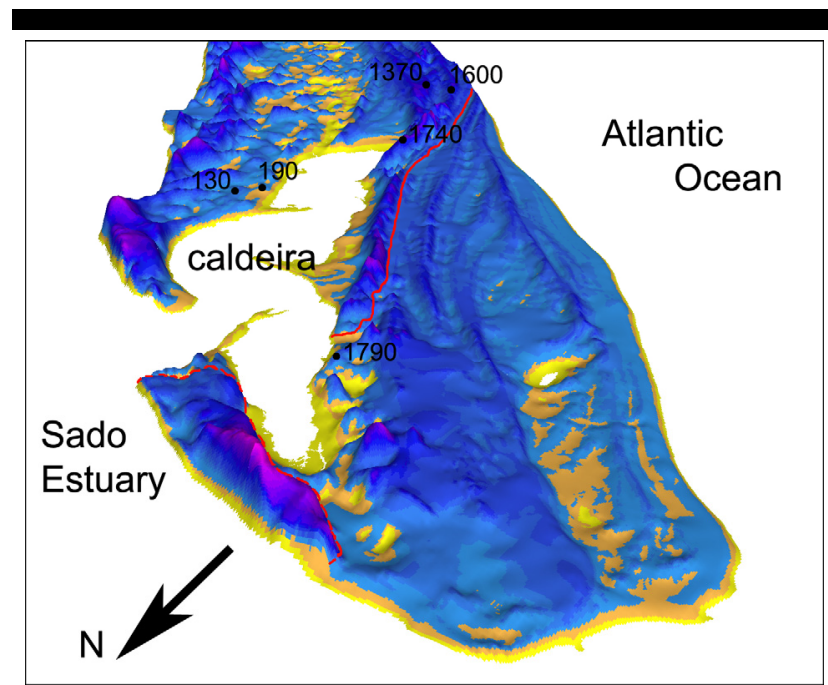

Figure 8. Digital terrain model of the north part of Tróia Peninsula. Red line marking the erosion front caused by the tsunami. Dunes to the right (west) of the red line are younger than the tsunami. Dune dates, in years A.D.

for this feature occurred sometime between $530 \pm 70$ and $1200 \pm 60$ (A.D.). A neat change in the vegetation cover occurs in parallel with the observed morphologic changes.

In the northern tip of the barrier, the limit between pre-and posttsunami features are not so evident, although pos-tsunami age foredunes dominate.

Pre-tsunami foredunes, trending SE-NW, were eroded (figure 5) and the subsequent dune succession started to grow with a different orientation, closer to SSW-NNW. From the morphological standpoint, the barrier that separates the lagoon from the ocean side shows a continuous pattern from south to north until its mid-sector. However, to the north, the dune loses its continuity and reveals a more fragmented aspect (figure 8). These morphologies suggest breaching processes to explain the formation of pedestal structures, usually formed associated to tsunami events (Goff, 2009). Moreover, the lagoon reveals a flat deposit joining the two sides of the lagoon in the backbarrier area of the fragmented sector due to overwash. These results suggest that the northern end of the barrier was almost entirely destroyed and subsequently rebuilt after the tsunami. OSL ages of the foredune bordering the lagoon set its formation before the tsunami. Ages obtained from the beaches beneath the foredune yielded an age of $880 \pm 70$ (A.D), while the age of the crest was dated at $1740 \pm 20$ (A.D.). In addition, it is notable that the foredune presents a transgressive behavior with a precipitation ridge facing east. Therefore, it is plausible that the dune existed before the tsunami but it was apparently remobilized as a consequence of the tsunami-generated destabilization. To the north foredunes were dated at $1790 \pm 20$ (A.D) indicating the subsequent growth and seaward progradation of the barrier. This indicates that the barrier was older than the tsunami, pre-tsunami dunes were severely eroded, but lower deposits, at beach level, were not reworked. Moreover, a dune scarp is found in the dunes located north, in the estuary side of the Caldeira. If a breach had occurred in the oceanic side of the Caldeira during the tsunami, that could also explain the dune erosion in the northern margin of the Caldeira overture (figure 8).

Foredune ridge sequence (figure 5) analysis indicates that since the tsunami event, the northern tip of the peninsula has widened 
significantly (941 $\mathrm{m}$ at its maximum), at a rate of approximately $3.7 \mathrm{my}^{-1}$ between 1755 and 2005 .

\section{The longshore variability of the erosion}

Assuming that the coastline shape was consequence of the tsunami, some reason had to exist to focus the erosion on those two areas. The south indentation is geographically related to the merging of the southeast edge of River Sado ebb-tide delta sand body (figure 4) with the peninsula. The combination of the underwater morphology due to this sand body and the orientation of the peninsula creates the natural conditions to concentrate the flow of an incoming large wave in that area and hence, should have been responsible for an increased localized erosion, making plausible a coastal retreat in that sector.

The second indentation, closer to the north tip of the peninsula, may be explained by the flow acceleration due to the funnel effect of the river mouth. A decrease on the available section due to the restriction caused by the Arrábida Chain, at north, and the northern tip of the peninsula, at south, could have been responsible for an acceleration of the flow, leading to the erosion. The location of the marginal flood channel of the ebb-tide delta, parallel and close to the shore, could have played also a role in the increase of water transport to the northern tip, contributing to the more intense erosion in that area (figure 4).

\section{CONCLUSION}

The tsunami wave approaching from SW or WSW had a significant impact on the oceanic northern part of the peninsula in terms of erosion and reshaping the coastline.

Two curvilinear indentations were generated in the coast as a consequence of more focused wave action. The southern indentation is geographically related with the merging of the southeast edge of River Sado ebb-tide delta sand body with the peninsula. The combination of the underwater morphology and the orientation of the peninsula should have been responsible for increased localized erosion, making plausible a coastal retreat in that sector. The northern indentation should have been the result of the strong erosion generated by the water flow entering the estuary due to the funnel effect created by narrow estuary mouth.

Post-tsunami coastlines were $240 \mathrm{~m}$ distant, in the south indentation, and $930 \mathrm{~m}$ distant, in the northern indentation, from the 2005 coastline. Assuming that pre-tsunami and present day coastlines were both in equilibrium, the post-tsunami coastline progradation may give an indication about the coastline retreat and sediment quantity removed due to the tsunami.

Several indicators point to the possibility that the tsunami wave has breached the barrier and invaded the Caldeira lagoon, namely:

a) Breeching in the northern part of the Caldeira bordering dune

b) A flat sand deposit inside the lagoon at the back of that breach;

c) Erosion on northern margin of the lagoon facing the ocean;

d) Post-tsunami dune activity on top of sediments approximately 875 years older than the dunes.

Although typical tsunamigenic sediments were still not found, morphological, stratigraphic and dating evidences shows that the 1755 tsunami had a strong impact on eroding and reshaping the Tróia Peninsula coast. The results document an erosion of a approximately 900 years of sedimentary history near the northern tip and 400 years in the southern indentation.

\section{ACKNOWLEDGEMENT}

This research was partially founded by FCT research project SCARPS (PTDC/CTE-GIX/101466/2008).

\section{LITERATURE CITED}

Baptista, M.A., Miranda, J.M., 2009. Revision of the Portuguese catalog of tsunamis. Nat. Hazards Earth Syst. Sci. 9, 25-42.

Beltrán, C., 1993. Mapa neotectónico de Venezuela. Caracas, Venezuela: Departamento de Ciencias de la Tierra, scale 1:2,000,000, 1 sheet.Ferraz, M., 2007. Identificação e Caracterização das Dunas e Campos Dunares da Parte Norte da Península de Tróia. Departamento de Geologia da Faculdade de Ciências da Universidade de Lisboa, Master's thesis, $146 \mathrm{p}$.

Burbidge, C.I., Trindade, M.J., Cardoso, G.J.O., Dias, M.I., Oosterbeek, L., Cruz, A., Scarre, C., Cura, P., Caron, L., Prudêncio, M.I., Gouveia, A., Franco, D., Marques, R. Submitted. Luminescence dating and associated analyses in transition landscapes of the Alto Ribatejo, Central Portugal. Archaeometry.

Costa, P.J.M., Andrade, C., Freitas, M.C., Oliveira, M.A., Lopes, V., Dawson, A.G., Moreno, J., Fatela, F. and Jouanneau, J-M., 2012. A tsunami record in the sedimentar archive of the central Algarve coast, Portuga:: Characterizing sediment, reconstructing sources and inundation paths. The Holocene.

Folque, F., 1802., Topographic map, Trabalhos Geodésicos dos Reino, Portugal, scale 1:100,000, sheet 28 .

Font, E., Nascimento, C., Omira, R., Baptista, M.A. and Silva, P.F., 2010 Identification of tsunami-induced deposits using numerical modeling and rock magnetism techniques: A study case of the 1755 Lisbon tsunami in Algarve, Portugal. Physics of the Earth and Planetary Interiors, Volume 182, Issues 3-4, Pages 187-198.

Goff, J. R., Lane, E. \& Arnold, J. 2009. The tsunami geomorphology of coastal dunes. Nat. Hazards Earth Syst. Sci., 9, 847-854.

Gouveia, M.A., Prudêncio, M.I., Barros, J.S., Morgado, I., Cabral, J.M.P. 1994. Elemental concentration data for USGS geochemical exploration reference materials GXR-1 to GXR-4 and GXR-6. Journal of Radioanalytical and Nuclear Chemistry, Articles, 179 (1), p. 165-172.

Inselin, C., 1760. Map of the "Les Ports de Lisbonne et Setúbal”, graphical scale.

Instituto Hidrográfico, 1928. Hydrographic chart, Plano Hidrográfico da Barra e Porto de Setúbal. Direcção de Hidrografia, Navegação e Metereologia Náutica, edited in 1930, Ministério da Marinha, Lisboa, scale $1: 25,000,1$ sheet.

Martínez Solares, J.M., López Arroyo, A., 2004. The great historical 1755 earthquake. Effects and damage in Spain. Journal of Seismology 8, 275 294.

Psuty, N.P., 1992. Spatial variation in coastal foredune development, In R.W.G. Carter, T.G.F Curtis, M.J. Sheehy-Skeffington (ed), Coastal Dunes. Balkema, Rotterdam, pp. 3-13.

Rebêlo, L., Ferraz, M. and Brito, P., 2009. Tróia Peninsula Evolution: The Dune Morphology Record. Journal of Coastal Research, SI 56 (Proceedings of the 10th International Coastal Symposium), 352-355, Lisbon. Portugal.

Sensors \& Software 1993. Ekko-Tools User's Guide, Version 1.1, Technical Manual. 1.1. Mississauga, Canada, 138.

Vincendon, M. C. A., 1852. Hydrographic chart, edited in 1855, Dépôt Général de la Marine, France, scale 1:30,000, 1 sheet. 